\title{
Influence of Organic Manures, Biofertilizers and Wood Ash on Growth and Yield of Edible Podded Pea (Pisum sativum var. macrocarpon) var. Arka Apoorva
}

\author{
Pekila Bhutia*, P.S. Mariam Anal, P. Sarma, Amit Kumar Singh, \\ S. Romen Singh and A.S. Mailappa
}

College of Horticulture and Forestry, Central Agricultural University, Pasighat-795 102, Arunachal Pradesh, India

*Corresponding author

\section{A B S T R A C T}

Keywords

Edible podded pea, Organic manures, biofertilzers, Wood ash, Growth and yield

Article Info

Accepted:

04 July 2019

Available Online:

10 August 2019
The present investigations were conducted during the year 2017-18 and 201819 at Vegetable Research Farm, Department of Vegetable Science, College of Horticulture and Forestry, CAU, Pasighat, Arunachal Pradesh. The layout used in the experiments is Randomised Block Design with three replications and comprised of 14 treatments. Application of organic manures along with biofertilizers and wood ash increased the growth and yield of edible podded pea. The outcome uncovered that the application of vermi bonemeal @ 5t/ha, rhizobium, PSB and wood ash @ 0.5t/ha demonstrated significantly higher plant height, root length, fresh and dry shoot and root weight, no. of pods/plant, pod length, pod weight/plant and pod yield/ha. The minimum days taken to $50 \%$ flowering and fruiting as well node at which first flowering was recorded with vermi bonemeal @ 5t/ha, rhizobium, PSB and wood ash @ $0.5 \mathrm{t} / \mathrm{ha}$. The present investigation revealed that edible podded pea var. Arka Apoorva can be grown in Pasighat condition with the consolidated utilisation of vermi bonemeal with rhizobium, phosphate solubilising bacteria and wood ash for growth and higher yield.

\section{Introduction}

Pea is an important cool season vegetable crop belonging to the family fabaceae, originated in the near East and Mediterranean regions. In India, pea is commonly grown as a winter vegetable in the plains and as a summer vegetable in hills. As per available statistic, in
India, the region under pea is 5,46,000 hectare with a production of 54,52,000 MT and productivity is 10t/ha (Anon., 2017b). Garden pea is classified into three viz., Garden pea or shell peas (Pisum sativum L. var. hortense), Snow pea or Chinese pea (Pisum sativum var. saccharatum) and Snap pea or Sugar snap pea (Pisum sativum var. macrocarpon) (Myers et 
al., 2001). Both the snow pea and snap pea is edible podded pea where the whole pods are consumed. Garden peas are used as vegetable in the form of cooked, soup, canned, frozen or dehydrated. Tender shoots are nipped and used in salad preparation along with other vegetables which is very famous in $\mathrm{NEH}$ region particularly in Manipur. Pea is a very important off-season cash crop besides having ecological advantage due to fixation of atmospheric nitrogen through root nodules. Garden pea contains $7.2 \mathrm{~g}$ protein, $0.1 \mathrm{~g}$ fats, $0.8 \mathrm{~g}$ minerals, $15.8 \mathrm{~g}$ carbohydrates, $20 \mathrm{mg}$ calcium, $34 \mathrm{mg}$ magnesium, $139 \mathrm{mg}$ phosphorus, $0.23 \mathrm{mg}$ copper, $95 \mathrm{mg}$ sulphur, $1.5 \mathrm{mg}$ iron, $0.01 \mathrm{mg}$ riboflavin, $0.8 \mathrm{mg}$ nicotinic acid and $9.0 \mathrm{mg}$ vitamin $\mathrm{C}$ per $100 \mathrm{~g}$ of edible portion (Sepehya et al., 2015).

In general, shelling percentage of pea is about 50 to $60 \%$ in which the fresh seeds are used as vegetable and remaining 40 to $50 \%$ are discarded in the form of fibrous pod wall. To overcome the wastage, a new whole edible podded garden pea variety Arka Apoorva has been developed at IIHR, ICAR, Bangaluru as a choice vegetable which is grouped under var. macrocarpon. In India, the area and production of Arka Apoorva is $0.35 \mathrm{~m}$ ha and $2.91 \mathrm{MT}$ with a productivity of $8.31 \mathrm{t} / \mathrm{ha}$. It is rich in protein $(7.2 \%)$, vitamin, and minerals. It is moderately resistant to rust and powdery mildew. The pods are harvested when the seeds just begin to mature and the pods are still tender as well as at full maturity stage. The pods are $8-9 \mathrm{~cm}$ long and $2 \mathrm{~cm}$ breadth, succulent with crisp texture. Immature seeds are bold, dark green, smooth and sweet. It is processed, eaten raw as a salad or cooked. The crop duration of this variety is 90-100 days and yield potential is about 11 t/ha (Anon., 2017a).

As a short duration vegetable crop, pea requires a good amount of nutrients to provide better growth and yield. Nitrogen is important for chlorophyll, protein and enzyme synthesis. Phosphorus is essential for root growth, energy storage and nodulation. Potassium is used for enzyme activity and enhancing the translocation of assimilates and protein synthesis (Zaghlou et al., 2015)

Being a leguminous crop it improves the soil fertility by biological nitrogen fixation in association with symbiotic rhizobium prevalent in their root nodules and also leaves residual nitrogen of about $50-60 \mathrm{~kg} / \mathrm{ha}$ (Negi et al., 2006).

The use of synthetic inputs like chemical fertilizers in order to increase food production and productivity decreases soil fertility, soil microbiological activity, nutrient content of crops and leaves toxic residue leads to devastating impact on human, animal and soil health in a long run. The commercial application of organic manures with biofertilizers improved the yield, quality of pea, enhance the fertilizer use efficiency, nutrient cycling and microbiological activity (Sangma et al., 2018). The incorporation like vermicompost, FYM, and poultry manures increases the macronutrients and micro improves the soil aggregates, soil structure, aeration, $\mathrm{pH}$ and soil water holding capacity (Alabadan et al., 2009). It is operational in improving the soil organic carbon, nitrogen, phosphorus and potassium status. Biofertilizers are living micro-organisms that fixes atmospheric nitrogen and improves the uptake of phosphorus and other primary nutrients (Bhattacharjee et al., 2014).

Seeds when inoculated with rhizobium and Phosphate Solubilising Bacteria (PSB) obtained more pod yield as compared to the un-inoculated (Vaisya et al., 1983). Most of the North Eastern soil are acidic in nature and has low phosphorus content. Seeds inoculated with PSB increases the yield potential (Tilak and Annapurna, 1993). Hence, use of bio- 
fertilizers and organic manures is eco-friendly with high export demand and income generation of vegetable crops. Keeping in view the above certainty, the present investigation was undertaken.

\section{Materials and Methods}

The present investigations were carried out for two seasons during October to February, 2017-18 and 2018-19 at the Vegetable Research Farm, Department of Vegetable Science, College of Horticulture and Forestry, Central Agricultural University, Pasighat, Arunachal Pradesh. The geographical location of the research farm is situated at $28^{\circ} 06^{\wedge} \mathrm{N}$ latitude and $95^{\circ} 32^{`} \mathrm{E}$ longitude at an altitude of $153 \mathrm{~m}$ above mean sea level. The soil type is sandy loam with $\mathrm{pH} 5.2$, organic carbon $1.2 \%$, available nitrogen $350.33 \mathrm{~kg} / \mathrm{ha}$, available phosphorus $23.50 \mathrm{~kg} / \mathrm{ha}$ and available potassium $130.40 \mathrm{~kg} / \mathrm{ha}$.

The experiments were carried out in Randomised Block Design replicated thrice with 14 treatments under sandy loam condition. The treatment details were $T_{1}$ (FYM @ 10 t/ha + Rhizobium + PSB $), \mathrm{T}_{2}(\mathrm{PM}$ @ 5 t/ha + Rhizobium + PSB), T $(\mathrm{VBM} @ 5$ t/ha + Rhizobium + PSB), T 4 (VC @ 5 t/ha + Rhizobium + PSB), T5 (FYM @ 10 t/ha + Rhizobium + PSB + Wood ash @ $0.5 \mathrm{t} / \mathrm{ha}), \mathrm{T}_{6}$ (PM@ 5 t/ha + Rhizobium + PSB + Wood ash @ $0.5 \mathrm{t} / \mathrm{ha}), \mathrm{T}_{7}$ (VBM @ 5t/ha + Rhizobium + PSB + Wood ash@0.5 t/ha), T8 (VC@ 5 t/ha + Rhizobium + PSB + Wood ash @ 0.5 t/ha),T $(F Y M @ 10$ t/ha, T10 (PM @ 5 t/ha), $\mathrm{T}_{11}$ (VBM@ $\left.5 \mathrm{t} / \mathrm{ha}\right), \mathrm{T}_{12}$ (VC @ $5 \mathrm{t} / \mathrm{ha}$ ), $\mathrm{T}_{13}$ (Wood ash@0.5 t/ha), T 14 (Control).

Organic manures such as well decomposed Farm Yard Manure (FYM) @ 10t/ha, Poultry Manure (PM) @ 5t/ha, Vermi bonemeal (VBM)@5t/ha, Vermicompost (VC) @ 5t/ha and Wood ash @ 0.5t/ha were applied and incorporated according to the treatments in respective plots 20 days before sowing of seeds. Seeds were inoculated with biofertilizers such as PSB and rhizobium (Rhizobium legumninosarum) and dried in shade for few hours followed by sowing. Biofertilizers at the rate of $20 \mathrm{~g} / \mathrm{kg}$ seeds were mixed well with sugar solution to moisten and adhered to the seeds. The seed of edible podded pea var. Arka Apoorva at the rate of $50 \mathrm{~kg} / \mathrm{ha}$ was sown $3 \mathrm{~cm}$ depth maintaining a spacing of $60 \times 10 \mathrm{~cm}$. Cultural operations like weeding, earthing up and irrigation are followed in all the treatments.

\section{Results and Discussion}

The growth characters like plant height, root length, fresh and dry weight of shoot, fresh and dry weight of root are maximum with the application of vermi bonemeal along with biofertilizers and wood ash $\left(\mathrm{T}_{7)}\right.$. The combination of organic manures like vermi bonemeal along with biofertilizers and wood ash decreases the number of nodes at which first flower appear was also reported with $\mathrm{T}_{7}$ (Table 1 and 2). This was closely followed by incorporation of vermicompost along with biofertilizers and wood ash $\left(\mathrm{T}_{8}\right)$. It may be attributed due to adequate availability of micro and macro nutrients from the organic sources which improve the growth characters of the garden pea. Organic manures, biofertilizers and wood ash are a good source of growth promoting hormones, enzymes, N, P, K, Ca and $\mathrm{Mg}$ which resulted in increased plant growth. It also improves the soil health, root penetration, increases microbial activity, water holding capacity, good drainage facilities and enhances nutrient status. The benefit of adequate supply of plant nutrients from organic sources and their influences on plant height was reported earlier by Gupta et al., (2017) and Mishra et al., (2014) in pea. The present findings are also in line with the earlier work reported by Bajracharya and Rai (2000) in chickpea. 
Table.1 Effect of organic manures and biofertilizers on plant height, no. of nodes at which first flower appear, fresh and dry weight of root of edible podded pea

\begin{tabular}{|c|c|c|c|c|c|c|c|c|c|c|c|c|c|c|c|c|c|c|}
\hline \multirow{3}{*}{$\begin{array}{c}\text { Treatme } \\
\text { nt }\end{array}$} & \multicolumn{9}{|c|}{ Plant height (cm) } & \multirow{2}{*}{\multicolumn{3}{|c|}{$\begin{array}{c}\text { No. of nodes at which } \\
\text { first flower appear 2018- } \\
19\end{array}$}} & \multirow{2}{*}{\multicolumn{3}{|c|}{ Root fresh weight (g) }} & \multirow{2}{*}{\multicolumn{3}{|c|}{ Root dry weight (g) }} \\
\hline & \multicolumn{3}{|c|}{30 DAS } & \multicolumn{3}{|c|}{60 DAS } & \multicolumn{3}{|c|}{ 2017-18 } & & & & & & & & & \\
\hline & $\begin{array}{c}2017- \\
18\end{array}$ & $\begin{array}{c}\text { 2018- } \\
19\end{array}$ & Pooled & $\begin{array}{c}2017- \\
18\end{array}$ & $\begin{array}{c}\text { 2018- } \\
19\end{array}$ & $\begin{array}{c}\text { Poole } \\
\text { d }\end{array}$ & $\begin{array}{c}2017- \\
18\end{array}$ & $\begin{array}{c}2018- \\
19\end{array}$ & Pooled & $\begin{array}{c}\text { 2017- } \\
18\end{array}$ & 2018-19 & Pooled & 2017-18 & 2018-19 & Pooled & 2017-18 & 2018-19 & Pooled \\
\hline T1 & 11.40 & 12.00 & 11.70 & 27.36 & 27.95 & 27.66 & 59.50 & 60.47 & 59.99 & 13.44 & 13.20 & 13.32 & 5.99 & 6.00 & 6.00 & 0.62 & 0.75 & 0.69 \\
\hline $\mathbf{T} 2$ & 11.63 & 12.33 & 11.98 & 28.69 & 29.00 & 28.85 & 62.59 & 63.62 & 63.10 & 13.60 & 13.60 & 13.60 & 6.02 & 6.20 & 6.11 & 0.69 & 0.80 & 0.74 \\
\hline T3 & 12.14 & 12.57 & 12.36 & 32.10 & 33.74 & 32.92 & 65.54 & 66.60 & 66.07 & 13.00 & 12.80 & 12.90 & 6.48 & 6.50 & 6.49 & 0.76 & 0.91 & 0.84 \\
\hline T4 & 11.79 & 12.39 & 12.09 & 33.31 & 35.00 & 34.16 & 67.46 & 67.50 & 67.48 & 13.30 & 13.30 & 13.30 & 6.23 & 6.47 & 6.35 & 0.71 & 0.88 & 0.80 \\
\hline T5 & 11.64 & 12.41 & 12.03 & 30.23 & 30.67 & 30.45 & 59.90 & 60.70 & 60.30 & 13.33 & 13.00 & 13.17 & 6.01 & 6.35 & 6.18 & 0.63 & 0.83 & 0.73 \\
\hline T6 & 12.36 & 12.76 & 12.56 & 34.67 & 35.00 & 34.83 & 67.28 & 66.67 & 66.98 & 13.50 & 13.40 & 13.45 & 6.05 & 6.30 & 6.18 & 0.70 & 0.89 & 0.79 \\
\hline T7 & 12.20 & 12.63 & 12.42 & 35.50 & 37.00 & 36.25 & 68.65 & 69.67 & 69.16 & 12.80 & 12.00 & 12.40 & 6.52 & 6.83 & 6.68 & 0.79 & 1.01 & 0.90 \\
\hline T8 & 11.91 & 12.53 & 12.22 & 35.23 & 35.50 & 35.36 & 67.72 & 68.33 & 68.02 & 13.00 & 12.53 & 12.77 & 6.30 & 6.61 & 6.45 & 0.75 & 0.97 & 0.86 \\
\hline T9 & 10.23 & 10.43 & 10.33 & 22.23 & 23.02 & 22.63 & 52.55 & 53.33 & 52.94 & 14.22 & 14.00 & 14.11 & 4.44 & 6.15 & 5.30 & 0.41 & 0.51 & 0.46 \\
\hline T10 & 11.02 & 11.67 & 11.35 & 23.90 & 26.33 & 25.12 & 55.71 & 59.80 & 57.75 & 14.33 & 14.33 & 14.33 & 4.84 & 4.80 & 4.82 & 0.44 & 0.52 & 0.48 \\
\hline T11 & 10.97 & 11.30 & 11.14 & 23.00 & 24.60 & 23.80 & 54.93 & 57.50 & 56.22 & 14.00 & 13.88 & 13.94 & 4.84 & 4.92 & 4.90 & 0.48 & 0.49 & 0.49 \\
\hline T12 & 10.72 & 11.31 & 11.02 & 23.20 & 24.94 & 24.07 & 55.38 & 56.50 & 55.94 & 13.88 & 13.38 & 13.63 & 4.77 & 5.00 & 4.89 & 0.46 & 0.54 & 0.50 \\
\hline T13 & 9.69 & 10.27 & 9.98 & 21.30 & 22.00 & 21.65 & 50.77 & 51.53 & 51.15 & 15.00 & 14.25 & 14.63 & 4.24 & 4.39 & 4.32 & 0.37 & 0.55 & 0.46 \\
\hline T14 & 9.44 & 10.04 & 9.74 & 17.30 & 16.94 & 17.12 & 41.34 & 41.50 & 41.42 & 15.33 & 15.60 & 15.47 & 3.16 & 3.20 & 3.18 & 0.30 & 0.40 & 0.35 \\
\hline SEd \pm & 1.01 & 0.97 & 0.71 & 1.21 & 1.79 & 1.07 & 1.27 & 1.43 & 0.94 & 0.28 & 0.31 & 0.21 & 0.10 & 0.12 & 0.08 & 0.01 & 0.02 & 0.01 \\
\hline $\mathrm{CD}_{0.05}$ & NS & NS & NS & 2.50 & 3.70 & 2.16 & 2.62 & 2.96 & 1.90 & 0.58 & 0.64 & 0.42 & 0.20 & 0.26 & 0.16 & 0.02 & 0.04 & 0.02 \\
\hline
\end{tabular}


Table.2 Effect of organic manures and biofertilizers on root length $(\mathrm{cm})$, fresh and dry weight of shoot of edible podded pea

\begin{tabular}{|c|c|c|c|c|c|c|c|c|c|c|c|c|c|c|c|}
\hline \multirow[t]{2}{*}{ Treatment } & \multicolumn{3}{|c|}{ Root length at 30 DAS } & \multicolumn{3}{|c|}{ Root length at 60 DAS } & \multicolumn{3}{|c|}{ Root length at 90 DAS } & \multicolumn{3}{|c|}{ Shoot fresh weight (g) } & \multicolumn{3}{|c|}{ Shoot dry weight (g) } \\
\hline & 2017-18 & 2018-19 & Pooled & 2017-18 & 2018-19 & 2017-18 & 2018-19 & 2017-18 & Pooled & 2017-18 & 2018-19 & Pooled & 2017-18 & 2018-19 & Pooled \\
\hline T1 & 9.34 & 10.00 & 9.67 & 17.22 & 18.00 & 17.61 & 27.46 & 28.33 & 27.89 & 61.25 & 61.55 & 61.40 & 3.80 & 3.82 & 3.81 \\
\hline $\mathbf{T} 2$ & 9.86 & 10.60 & 10.23 & 17.70 & 18.83 & 18.27 & 28.02 & 28.99 & 28.51 & 68.51 & 73.00 & 70.76 & 3.85 & 4.02 & 3.94 \\
\hline T3 & 10.30 & 11.00 & 10.65 & 19.25 & 19.72 & 19.49 & 32.02 & 32.07 & 32.04 & 80.20 & 79.96 & 80.08 & 4.10 & 4.08 & 4.08 \\
\hline T4 & 10.03 & 10.70 & 10.37 & 19.04 & 19.69 & 19.36 & 30.11 & 30.90 & 30.51 & 77.14 & 74.85 & 76.00 & 3.97 & 3.98 & 3.97 \\
\hline T5 & 9.99 & 10.30 & 10.15 & 17.28 & 18.03 & 17.66 & 28.00 & 28.99 & 28.49 & 63.97 & 63.68 & 63.83 & 3.89 & 3.90 & 3.90 \\
\hline T6 & 10.27 & 10.80 & 10.54 & 19.57 & 20.33 & 19.95 & 31.30 & 31.53 & 31.42 & 78.33 & 76.32 & 77.33 & 4.01 & 4.09 & 4.05 \\
\hline T7 & 10.37 & 11.30 & 10.84 & 19.83 & 20.58 & 20.20 & 32.57 & 33.00 & 32.78 & 82.96 & 86.66 & 84.81 & 4.22 & 4.30 & 4.26 \\
\hline T8 & 10.00 & 10.40 & 10.20 & 19.61 & 20.52 & 20.07 & 31.58 & 32.50 & 32.04 & 78.93 & 84.10 & 81.52 & 4.06 & 4.16 & 4.11 \\
\hline T9 & 8.11 & 8.80 & 8.46 & 14.00 & 14.92 & 14.47 & 22.21 & 22.54 & 22.38 & 47.30 & 50.04 & 48.67 & 3.01 & 3.28 & 3.14 \\
\hline T10 & 9.07 & 9.70 & 9.39 & 14.42 & 15.07 & 14.76 & 26.12 & 27.00 & 26.56 & 49.99 & 50.66 & 50.33 & 3.11 & 3.20 & 3.15 \\
\hline T11 & 8.63 & 9.10 & 8.87 & 14.32 & 14.34 & 14.33 & 24.01 & 25.58 & 24.79 & 50.48 & 51.41 & 50.95 & 2.91 & 3.39 & 3.15 \\
\hline T12 & 8.51 & 8.80 & 8.66 & 14.30 & 14.53 & 14.42 & 22.70 & 24.00 & 23.35 & 50.72 & 54.10 & 52.41 & 3.22 & 3.32 & 3.27 \\
\hline T13 & 7.74 & 8.40 & 8.07 & 11.23 & 12.27 & 11.75 & 18.30 & 20.00 & 19.15 & 42.34 & 44.00 & 43.17 & 3.08 & 3.10 & 3.09 \\
\hline T14 & 6.41 & 7.10 & 6.76 & 10.22 & 10.20 & 10.21 & 17.00 & 16.50 & 16.75 & 38.00 & 37.11 & 37.56 & 2.19 & 2.50 & 2.35 \\
\hline SEd \pm & 1.27 & 1.18 & 0.79 & 0.34 & 0.62 & 0.36 & 0.64 & 0.61 & 0.43 & 2.45 & 1.79 & 1.51 & 0.10 & 0.12 & 0.08 \\
\hline $\mathrm{CD}_{0.05}$ & NS & NS & NS & 0.70 & 1.28 & 0.71 & 1.32 & 1.25 & 0.87 & 5.07 & 3.72 & 3.04 & 0.20 & 0.26 & 0.16 \\
\hline
\end{tabular}


Table.3 Effect of organic manures and biofertilizers on Days to 50\% flowering, fruiting, number of pods/plant and number of seeds/plant of edible podded pea

\begin{tabular}{|c|c|c|c|c|c|c|c|c|c|c|c|c|}
\hline \multirow[t]{2}{*}{ Treatment } & \multicolumn{3}{|c|}{ Days to $50 \%$ flowering } & \multicolumn{3}{|c|}{ Days to $50 \%$ fruiting } & \multicolumn{3}{|c|}{ Number of pods/plant } & \multicolumn{3}{|c|}{ Number of seeds/plant } \\
\hline & 2017-18 & 2018-19 & Pooled & 2017-18 & 2018-19 & Pooled & 2017-18 & 2018-19 & Pooled & 2017-18 & 2018-19 & Pooled \\
\hline T1 & 50.33 & 49.62 & 49.98 & 70.33 & 69.55 & 69.94 & 11.16 & 12.26 & 11.71 & 6.10 & 6.10 & 6.10 \\
\hline $\mathbf{T} 2$ & 50.67 & 50.31 & 50.49 & 69.67 & 70.23 & 69.95 & 11.00 & 12.27 & 11.64 & 6.00 & 6.10 & 6.05 \\
\hline T3 & 48.00 & 47.79 & 47.90 & 67.70 & 67.49 & 67.60 & 12.00 & 13.71 & 12.86 & 6.40 & 6.40 & 6.40 \\
\hline T4 & 48.07 & 47.75 & 47.91 & 68.91 & 67.75 & 68.33 & 12.00 & 13.57 & 12.78 & 6.27 & 6.30 & 6.29 \\
\hline T5 & 49.33 & 47.94 & 48.64 & 69.33 & 67.94 & 68.64 & 11.80 & 13.06 & 12.43 & 6.20 & 6.20 & 6.20 \\
\hline T6 & 52.33 & 50.33 & 51.33 & 72.23 & 70.34 & 71.29 & 11.13 & 12.61 & 11.87 & 6.20 & 6.30 & 6.25 \\
\hline T7 & 46.00 & 43.80 & 44.90 & 65.50 & 64.00 & 64.75 & 13.20 & 15.17 & 14.18 & 6.54 & 6.66 & 6.60 \\
\hline T8 & 46.33 & 45.66 & 46.00 & 66.22 & 66.00 & 66.11 & 12.73 & 14.30 & 13.52 & 6.30 & 6.50 & 6.40 \\
\hline T9 & 54.00 & 52.88 & 53.44 & 74.17 & 72.77 & 73.47 & 10.03 & 11.26 & 10.65 & 5.96 & 6.00 & 5.98 \\
\hline T10 & 55.67 & 53.96 & 54.82 & 75.66 & 73.96 & 74.81 & 10.00 & 10.83 & 10.42 & 5.80 & 6.00 & 5.90 \\
\hline T11 & 53.67 & 52.32 & 53.00 & 73.56 & 72.32 & 72.94 & 10.90 & 11.73 & 11.32 & 6.00 & 6.00 & 6.00 \\
\hline T12 & 52.33 & 50.16 & 51.25 & 73.89 & 70.15 & 72.02 & 10.60 & 11.30 & 10.95 & 6.00 & 6.00 & 6.00 \\
\hline T13 & 55.67 & 53.89 & 54.78 & 75.69 & 74.20 & 74.95 & 8.70 & 8.93 & 8.82 & 5.90 & 5.90 & 5.90 \\
\hline T14 & 56.00 & 55.56 & 55.78 & 79.00 & 80.33 & 79.67 & 8.00 & 7.90 & 7.95 & 5.60 & 5.50 & 5.55 \\
\hline SEd \pm & 0.92 & 0.99 & 0.72 & 1.30 & 1.40 & 0.067 & 0.24 & 0.32 & 0.20 & 0.24 & 0.30 & 0.19 \\
\hline $\mathrm{CD}_{0.05}$ & 1.91 & 2.04 & 1.44 & 2.68 & 2.98 & 1.94 & 0.49 & 0.66 & 0.40 & 0.12 & 0.10 & 0.09 \\
\hline
\end{tabular}


Table.4 Effect of organic manures and biofertilizers on pod length, girth, pod weight and pod yield of edible podded pea

\begin{tabular}{|c|c|c|c|c|c|c|c|c|c|c|c|c|}
\hline \multirow[t]{2}{*}{ Treatment } & \multicolumn{3}{|c|}{ Pod length (cm) } & \multicolumn{3}{|c|}{ Pod girth $(\mathrm{cm})$} & \multicolumn{3}{|c|}{ Pod weight/plant (g) } & \multicolumn{3}{|c|}{ Pod yield/ha (q) } \\
\hline & 2017-18 & 2018-19 & Pooled & 2017-18 & 2018-19 & Pooled & 2017-18 & 2018-19 & Pooled & 2017-18 & 2018-19 & Pooled \\
\hline T1 & 8.30 & 8.47 & 8.38 & 4.17 & 4.47 & 4.32 & 68.07 & 74.24 & 71.16 & 87.77 & 88.12 & 87.95 \\
\hline $\mathbf{T 2}$ & 8.27 & 8.40 & 8.34 & 4.05 & 4.30 & 4.18 & 66.00 & 72.00 & 69.00 & 82.92 & 84.1 & 83.51 \\
\hline T3 & 8.41 & 8.62 & 8.52 & 4.22 & 4.52 & 4.37 & 79.00 & 81.30 & 80.15 & 94.36 & 96.2 & 95.28 \\
\hline $\mathbf{T 4}$ & 8.40 & 8.57 & 8.49 & 4.10 & 4.40 & 4.25 & 76.67 & 79.67 & 78.17 & 93.64 & 94.64 & 94.14 \\
\hline T5 & 8.39 & 8.53 & 8.46 & 4.40 & 4.59 & 4.49 & 73.21 & 79.20 & 76.21 & 91.83 & 92.00 & 91.92 \\
\hline T6 & 8.30 & 8.50 & 8.40 & 4.20 & 4.43 & 4.32 & 70.84 & 78.60 & 74.72 & 86.86 & 88.30 & 87.58 \\
\hline $\mathbf{T 7}$ & 8.70 & 8.83 & 8.77 & 4.60 & 4.73 & 4.67 & 83.16 & 90.00 & 86.58 & 98.77 & 100.00 & 99.39 \\
\hline T8 & 8.59 & 8.70 & 8.65 & 4.30 & 4.63 & 4.47 & 80.55 & 86.00 & 83.27 & 96.83 & 98.50 & 97.67 \\
\hline T9 & 8.02 & 8.13 & 8.08 & 3.92 & 4.16 & 4.04 & 60.18 & 66.00 & 63.09 & 69.54 & 71.24 & 70.39 \\
\hline T10 & 7.99 & 8.10 & 8.05 & 3.87 & 4.15 & 4.01 & 60.00 & 65.58 & 62.79 & 65.74 & 67.34 & 66.54 \\
\hline T11 & 8.13 & 8.27 & 8.20 & 4.00 & 4.27 & 4.13 & 65.90 & 70.38 & 68.14 & 76.50 & 78.12 & 77.31 \\
\hline T12 & 8.19 & 8.33 & 8.26 & 3.98 & 4.23 & 4.11 & 61.66 & 67.80 & 64.73 & 74.20 & 78.08 & 76.14 \\
\hline T13 & 8.11 & 7.87 & 7.99 & 3.83 & 4.17 & 4.00 & 53.00 & 54.90 & 53.95 & 45.90 & 46.82 & 46.36 \\
\hline T14 & 7.50 & 7.50 & 7.50 & 3.77 & 3.97 & 3.87 & 48.00 & 45.08 & 46.54 & 42.10 & 40.85 & 41.48 \\
\hline SEd \pm & 0.17 & 0.19 & 0.13 & NS & NS & NS & 1.70 & 2.18 & 1.36 & 1.84 & 1.66 & 1.22 \\
\hline $\mathrm{CD}_{0.05}$ & 0.36 & 0.39 & 0.25 & 0.39 & 0.28 & 0.34 & 3.51 & 4.51 & 2.74 & 3.79 & 3.45 & 2.45 \\
\hline
\end{tabular}


Kumar (2016) and Mishra et al., (2010) reported that the increase supply of nutrients induce more vegetative growth which increases more fresh weight and dry matter content of shoots in pea.

The yield and yield attributing parameters like, number of pods/plant, number of seeds/pod, pod length, pod girth, pod weight/plant and pod yield per hectare were maximum with vermi bone meal along with biofertilizers and wood ash $\left(\mathrm{T}_{7}\right)$. The minimum days to $50 \%$ flowering and $50 \%$ fruiting was also reported in $\mathrm{T}_{7}$ (Table 3 and 4). This may be due to the adequate supply of both macro and micro nutrients from the organic sources, biofertilizers and wood ash in a slow rate which increases the metabolic activities, balance $\mathrm{C}$ : $\mathrm{N}$ ratio and build-up of carbohydrates. This leads to better vegetative growth and manufacture of food materials which are then translocated to the developing fruit and ultimately led to increase the number of pods per plant, number of seeds per pod, length of pod, pod girth, weight of pods/plant and pod yield/ha. The supply of nitrogen promotes succulent vegetative growth as well as reproductive phase. Gupta et al., (2017), Kothyari et al., (2017) and Mishra et al., (2014) also reported the benefit of adequate supply of nutrients on days to $50 \%$ flowering and fruiting in pea.

The positive influence of the nutrients on number of pods per plant is also reported by Ajala et al., (2017) in jicama crop. Similar results were recorded earlier by Lalilto et al., (2018), Ganie et al., (2009) and Susheela et al., (2007). Gopinath and Mina (2011), and Rather et al., (2010) also reported similar result from their studies. The findings were also reported by Lazarovits et al., (2000), Valenzuela et al., (2000) and Salomonsson et al., (1995 and 1994) that the yield of crops were increased due to the application of bone meal.
Based on the findings from two years, it may be concluded that combined application of vermi bone meal at $5 \mathrm{t} / \mathrm{ha}$, biofertilizers and wood ash at $0.5 \mathrm{t} /$ ha gave better growth and yield of edible podded pea variety Arka Apoorva under Pasighat condition.

\section{References}

Ajala, R., Awodun, M. and Oladela, S. (2017). Effect of wood ash biomass application on growth indices and chlorophyll content of maize and lima bean intercrop. Turkish J. of Agriculture: Food Science and Technology, 5(6): 614-621.

Alabadan, B.A., Adeoye, P.A. and Folorunso, E.A. (2009). Effect of different poultry wastes on physical, chemical and biological properties of soil. Caspian J. Env. Sci., 7(1): 31-35.

Anonymous, (2017a).A new whole pod edible dual-purpose pea variety Arka Apoorva. Indian Institute of Horticultural Research. https: //www.iihr.res.in/newwhole-pod-edible-dual-purpose-peavariety-arka-apoorva. Accessed 5 January, 2018.

Anonymous, (2017b). Horticultural Statistics at a glance, Department of Agriculture, Cooperation and Farmers welfare, Ministry of Agriculture and Farmers Welfare, Horticulture Statistic Division, Govt. of India. p. 16.

Bajracharya, S.K. and Rai, S.K. (2009). Effect of vermicompost on the nodulation and the yield of chickpea. Nepal Agric. Res. J., 6: 49-54.

Bhattacharjee, R. and Dey, U. (2014).Biofertilizer, a way towards organic agriculture: A review. Afr. $J$. Microbiol. Res., 8(24): 2332-2342.

Brar, N.S., Thakur, K.S., Kumar, R., Mehta, D.K., Sharma, N., Kumar, D. and Kumar, S. (2015). Effect of organic manures and biofertilizers on fruit yield 
and its contributing traits of tomato. Eco. Env. Cons., 21(4): 1783-1787.

Ganie, M.A.; Akhter, F.; Bhat, M.A.; Najar, G.R. (2014).Growth, yield and quality of French bean (Phaseolus vulgaris L.) as influenced by sulphur and boron application on inceptisols of Kashmir. Bioscan, 9: 513-518.

Gopinath, K.A. and Mina, B.L. (2011).Effect of organic manures on agronomic and economic performance of garden pea (Pisum sativum) and on soil properties. Indian J. Agri. Sci., 81(3): 236-239.

Gupta, S., Singh, D.P., Kasera, S. and Maurya, S.K. (2017). Effect of Integrated nutrient management on growth and yield attributes of table pea (Pisum sativum L.) cv. AP-3. Int. J. Chem. Stud., 5(6): 906-908.

Kothyari, H.S., Yadav, L.K. Jat, R. and Gurjar, P.C. (2017). Influence of biofertilizers on plant growth and seed yield of pea (Pisum sativum L.). Int. J. Curr. Microbiol. App. Sci., 6(11): 18101817.

Kumar, V.S. (2016). Performance of garden pea (Pisum sativum var. hortense L.) varieties under conventional and organic nutrient sources. M.Sc. Thesis, submitted to Uttar Bangal Krishi Vishwavidyalaya, Pundibari, Coochbehar, West Bengal.

Lalito, C., Bhandari, S., Sharma, V. and Yadav, S.K. (2018). Effect of different organic and inorganic nitrogenous fertilizers on growth, yield and soil properties of pea.J. Pharmacogn. Phytochem., 7(4): 2114-2118.

Lazarovits, G., Conn, K. and Potter, J. (1999). Reduction of potato scab, verticillium wilt, and nematodes by soymeal and meat and bone meal in two Ontario potato fields, Can. J. Plant Pathol., (21): 345-353, (62): 309-319.

Mishra, A.; Prasad, K. and Rai, G. (2010). Effect of bio-fertilizer inoculations on growth and yield of dwarf field pea (Pisum sativum L.) in conjunction with different doses of chemical fertilizers. $J$. of Agron., 9(4): 163-168.

Mishra, N., Mahapatra, P., Mohanty, S. and Pradhan, M. (2014). Effect of soil amelioration, inorganic, organic and bio-fertilzers application on yield, quality and economics of snow pea (Pisum sativum L. var. macrocarpon). J. crop weed, 10(1): 48-52.

Myers, J.R., J.R. Baggett, and C. Lamborn (2001). Origin, history, and genetic improvement of the snap pea (Pisum sativum L.). Plant Breed. Rev. 21: 93138.

Negi, S., Singh, R.V. and Dwivedi, O.K. (2006). Effects of biofertilizers, nutrient sources and lime on growth and yield of garden pea. Leg. Res., 29(4): 282-285.

Rather, S.A., Hussain, M.H. and Sharma, N.L. (2010). Effect of biofertizers on growth, yield and economics of field pea (Pisum sativum L.). Int. J. Agric. Sci., 6(1): 65-66.

Salomonsson, L., Jonsson, A., Salomonsson, A. and Nilsson, G. (1994). Effects of organic fertilizers and urea when applied to spring wheat. Acta agric. Scandinavica. Section B, Soil and plant science, 44(3): 170.

Sangma, T.T.A., Saikia, L., Baruah, R. and Khatemenla. (2018). Organic and inorganic fertilizer amendments on sustainable health of garden pea. Int. J. Curr. Microbiol. App. Sci., 7(4): 36643672.

Sepehya, S., Bhardwaj, S.K. and Dhiman, S. (2015). Quality attributes of garden pea (Pisum sativum L.) as influenced by integrated nutrient management under mid hills conditions. J. Krishi Vigyan, 3(2): 78-83.

Sharma, U. and Chauhan, J.K. (2011).Influences of integrated use of inorganic and organic sources of 
nutrients on growth and production of pea. J. Farm Sci., 1(1): 14-18.

Singh, A.K. and Syamal, M.M. (2011). Nodules as influenced by Rhizobium inoculation, phosphorus application and their interaction in cowpea [Vigna unguiculata (L.) Walp]. Vegetable Sci., 38(1): 82-84.

Susheela, Negi, Dwivedi, G.K. and Singh, R.V (2007). Integrated nutrient management through biofertilizers, fertilizers organic manure and lime for vegetable pea in an acid inceptisol of cool, temperate Region. of Uttaranchal. Legume Res., 30 (1): 37-40.

Vaisya, U.K., Gayendragadhar. G.R. and
Pandey, R.L. (1983). Effect of Rhizobium inoculation on nodulation and seed yield of mungbean (Wilczek). Indian J. Microbil, 23: 228-230.

Valenzuela, H.R., Goo, T., Hamasaki, R.H and Radovich, T. (2000). The effect of bone meal on the yield of Jicama, Pachyrhizus erosus, in Hawaii. Proc. Fla. State Hort. Soc., 113: 222-226.

Zaghlou, R.A., Abou, H.E., Rasha, M.E. and Mohamed, T.E. (2015). Improvement of growth and yield of pea plants using integrated fertilization management. Universal J. Agri. Research, 3(4): 135143.

\section{How to cite this article:}

Pekila Bhutia, P.S. Mariam Anal, P. Sarma, Amit Kumar Singh, S. Romen Singh and Mailappa, A.S. 2019. Influence of Organic Manures, Biofertilizers and Wood Ash on Growth and Yield of Edible Podded Pea (Pisum sativum var. macrocarpon) var. Arka Apoorva. Int.J.Curr.Microbiol.App.Sci. 8(08): 210-219. doi: https://doi.org/10.20546/ijcmas.2019.808.025 